\title{
Intensive livestock farming as a major determinant of the exposure to anticoagulant rodenticides in raptors of the Canary Islands (Spain)
}

\author{
Cristian Rial-Berriel ${ }^{\mathrm{a}, 1}$, Andrea Acosta-Dacal a,1, Miguel Ángel Cabrera Pérez ${ }^{\mathrm{b}}$, Alejandro Suárez-Pérez ${ }^{\mathrm{c}}$, \\ Ayose Melián Melián d , Manuel Zumbado a,e, Luis Alberto Henríquez Hernández ${ }^{\mathrm{a}, \mathrm{e}}$, Norberto Ruiz-Suárez , \\ Ángel Rodriguez Hernández ${ }^{a}$, Luis D. Boada ${ }^{\mathrm{a}, \mathrm{e}}$, Ana Macías Montes ${ }^{\text {a }}$, Octavio P. Luzardo a,e,*

\footnotetext{
a Toxicology Unit, Research Institute of Biomedical and Health Sciences (IUIBS), University of Las Palmas de Gran Canaria, Paseo Blas Cabrera s/n, 35016 Las Palmas de Gran Canaria, Spain

b General Directorate to Combat Climate Change and the Environment, Biodiversity Service, Canary Islands Government, Plaza de los Derechos Humanos, 22,35071 Las Palmas de Gran Canaria, Spain

c “Tafira” Wildlife Recovery Center, Ctra. Del Centro, 35017 Las Palmas de Gran Canaria, Spain

d Gestión y Planeamiento Territorial y Medioambiental, S.A. (GESPLAN), Canary Islands Government, C / León y Castillo 54, bajo, 35003 Las Palmas de Gran Canaria, Spain

e Spanish Biomedical Research Center in Physiopathology of Obesity and Nutrition (CIBERObn), Spain
} \\ ${ }^{\mathrm{f}}$ Department of Nutrition, Genetics and Ethology, Faculty of Veterinary Medicine, Ghent University, Heidestraat 19, 9820 Merelbeke, Belgium
}

\section{H I G H L I G H T S}

- Exposure to AR in reptiles, mammals and non-raptor birds is mainly related to intentional poisoning.

- AR exposure appears as a threat for the conservation of the critically endangered Canary raven.

- Incidence of AR in raptors almost reach $60 \%$, with the highest values detected in common kestrels

- First report of AR residues in Barbary Falcon and Eleonora's Falcon

- Raptors that live near livestock intensive farms are significantly more exposed to AR.

\section{A R T I C L E I N F O}

\section{Article history:}

Received 24 September 2020

Received in revised form 18 November 2020

Accepted 4 December 2020

Available online 25 December 2020

Editor: Dimitra A Lambropoulou

\section{Keywords:}

Brodifacoum

Bromadiolone

Falco tinnunculus

Common buzzard

\section{G R A P H I C A L A B S T R A C T}

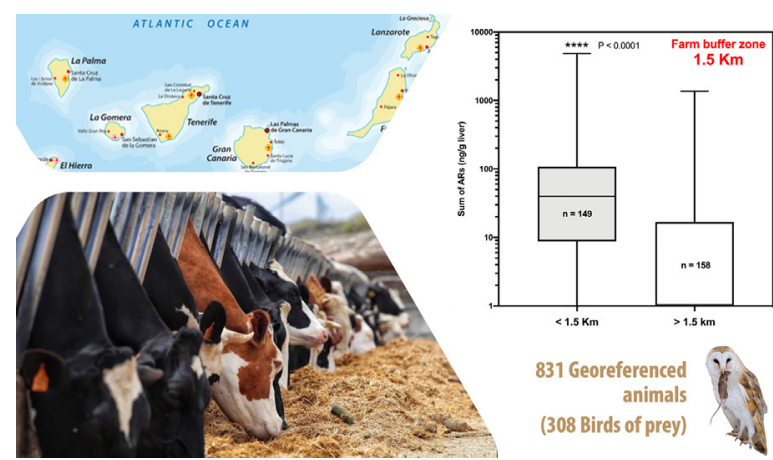

\begin{abstract}
A B S T R A C T
The Canary Islands (Spain) is a biodiversity hotspot, with more than 4500 registered endemic species. However, it is subject to high anthropogenic pressure that threatens its wildlife in various ways. In the context of forensic toxicological surveys, the presence of anticoagulant rodenticides (AR) has been investigated in the liver of 831 animal carcasses with georeferenced data from 2011 to May 2020. The high concentrations of toxic pesticides in carcasses and in baits found close to the corpses indicated that all the reptiles and most of the mammals tested positive for AR were intentionally poisoned, although mainly by other substances. The frequency of detection of AR in non-raptor birds $(\mathrm{n}=343)$ was only $4.1 \%$, being the Canary raven the most frequently affected species ( 7 / $97,7.2 \%)$. On the contrary, in raptors $(n=308)$ the detection frequency was almost $60 \%$, with an average of more than 2 ARs per animal. The highest concentrations were found in the common kestrel. We present for the firsttime results of AR contamination in two species of raptors that are very rare in Europe, Eleonora's falcon ( $\mathrm{n}=$ 4 ) and Barbary falcon $(n=13)$. The temporal trend of positive cases remains stable, but since the entry into force of the restriction to the concentration of the active ingredient in baits $(<30 \mathrm{ppm})$, a decrease in the
\end{abstract}

\footnotetext{
* Corresponding author at: Toxicology Unit, Clinical Sciences Department, Universidad de Las Palmas de Gran Canaria, Paseo Blas Cabrera Felipe s/n, 35016 Las Palmas, Spain. E-mail address: octavio.perez@ulpgc.es (O.P. Luzardo).

${ }^{1}$ These authors contributed equally to the work, and therefore should be considered indistinctly as first authors.
} 
Egyptian vulture

Owl concentrations of these compounds in the raptors' liver has been detected. Conversely, we registered an increase in the number of ARs per animal. From the study of the geographic information system (GIS) it can be deduced that intensive livestock farms are an important determinant in the exposure of raptors to ARs. Those birds that have their territory near intensive production farms have higher levels of exposure than those of birds that live far from such facilities.

\section{Introduction}

The annual use of anticoagulant rodenticides (AR) for rodents' control is estimated in thousands of tons (Hong et al., 2019). Most rodenticides belong to the group of anticoagulants, of which eight are EU-approved active ingredients (brodifacoum, bromadiolone, chlorophacinone, coumatetralyl, difenacoum, difethialone, flocoumafen and warfarin) (EC, 2017). These highly effective products interfere with the correct synthesis of the vitamin K-dependent clotting factors, thereby causing the rodents' death due to fatal bleeding (Watt et al., 2005). The second-generation products (SGARs; bromadiolone, difenacoum, brodifacoum, flocoumafen and difethialone) are highly resistant to degradation, reaching plasma half-lives of up to 91.7 days, and liver half-lives of up to 307.4 days, after a single exposure (Nakayama et al., 2019). After the exposure to SGARs, the exploratory behavior pattern of rodents changes, which results in a widening of its radius of action thus increasing the chances of being preyed upon (Frankova et al., 2019; Simon et al., 1994). All this leads to unintentional exposure to ARs in non-target wildlife, which has been documented in numerous reports around the world, many of them relating population declines to this exposure, especially in raptors (Nakayama et al., 2019). This threat was dramatically reflected in the article "Killing rats is killing birds", which had a substantial impact on public opinion (Lovett, 2012). However, almost ten years later, the threat continues, and the reported incidences in non-target species have barely diminished (Lohr and Davis, 2018; Lopez-Perea et al., 2015; Lopez-Perea et al., 2019; Nakayama et al., 2019; Seljetun et al., 2019). In 2014, our research group already presented results of a preliminary study in raptors of the Canary Islands (Ruiz-Suarez et al., 2014). In those findings we reported a frequency of ARs of around $61 \%$, although with a high variability among species, which is a similar percentage to those reported in raptors from other regions of Spain (Lopez-Perea et al., 2019), and from the rest of the world (Nakayama et al., 2019).

It would seem logical to think that for wildlife exposed to these ARs, these animals must live in an area relatively close to the sites where these compounds are applied (Geduhn et al., 2016; Lopez-Perea et al., 2019). This has recently been demonstrated in areas of high human population and livestock densities (Alabau et al., 2020; Lopez-Perea et al., 2019). In the case of livestock farming (intensive confinement, in particular) it is especially striking, since it is estimated that in some areas $>90 \%$ of them suffer from rat and mouse infestations (Endepols et al., 2003) because of its easy availability of food and shelter. The proliferation of rodents in these facilities provides excellent feeding opportunities for numerous species of opportunistic predators, which take advantage of anthropogenic environments, settling around farms, agricultural facilities and urban environments (Lopez-Perea et al., 2019). Nevertheless, on-farm application of rodenticides is often carried out irregularly, by personnel with little or no training at all in the application of pesticide products (in particular, on medium and small farms). The baiting points are often placed quite arbitrarily, and distributed based on subjective criteria, such as random detection of rodent activity (Endepols et al., 2003). In fact, this self-application of rodenticides by farmers is even facilitated by government agencies, given freely or subsidized, as part of the strategies to stimulate and support the livestock sector (Hong et al., 2019). Generally, a professional rodenticide service is only available in larger facilities. Partly due to the reasons outlined above, ARs have been pointed out by Lopez-Perea et al. (2019) as facilitators of what have been called "ecological traps" (Battin, 2004). Therefore, a habitat chosen by animals based on their chances of greater survival and better reproductive success may become a wrong option if an adverse environmental factor, such as the continued presence of ARs, is introduced (Battin, 2004; Lopez-Perea et al., 2019).

In the Canary Islands, the livestock sector is structured in two types of production: intensive livestock farming and traditional livestock farming. Intensive livestock farming, mainly dedicated to cattle, pigs and poultry, is normally found in the coastal strip of the islands, with a clear entrepreneurial character and higher technological level. Traditional livestock farms, mainly devoted to goats and sheep, are mostly located in the midlands, and characterized by a limited number of animals, whose diet is directly linked to agricultural activity and local fodder resources. Since 2010, our research group has received wildlife specimens from all the islands of the archipelago for the diagnosis of possible poisonings (more than 1300 animals recorded to date). Following the progressive implementation of the Poisoning Control and Prevention Strategy in the Canaries (BOC, 2014), the number of georeferenced incidents received has increased significantly. This fact allows us to locate with greater precision the habitat of these specimens and study the possible relationships with potential sources of exposure to chemicals and other stressors. Thus, the main objective of this research has been to investigate whether the presence of livestock activity, both intensive and traditional, is related to exposure to ARs in non-target wildlife.

\section{Material and methods}

\subsection{Geographic context, sampling and ethical statement}

This study was carried out in the Canary Islands, one of the so-called Outermost Regions of the European Union. This Spanish archipelago, located in the Atlantic Ocean off the northwest coast of Africa (between the coordinates $27^{\circ} 37^{\prime}$ and $29^{\circ} 25^{\prime}$ north latitude and $13^{\circ} 20^{\prime}$ and $18^{\circ}$ $10^{\prime}$ west longitude) consists of 8 inhabited islands and several uninhabited islets, all of volcanic origin. The archipelago occupies a land area of $7447 \mathrm{~km}^{2}\left(20.4 \%\right.$ of a total area of $\left.36,567 \mathrm{~km}^{2}\right)$. The islands are home to marine and terrestrial ecosystems of great value, both ecologically and in terms of landscape.

Due to the evolutionary isolation and climate characteristics, the biota of the archipelago has evolved differently from that of the nearby continents (Africa and Europe), giving rise to high levels of endemism. According to the updated data, in the Canary Islands there are almost 4500 endemic species, which represents more than $27 \%$ of the total biodiversity registered (https://www.biodiversidadcanarias.es/biota/). At present, the archipelago has a stable population of 2.1 million inhabitants and receives more than of 12 million tourists per year, putting enormous pressure on its ecosystems. However, the distribution of this anthropogenic pressure on the territory is irregular, since large environmentally protected areas have been recognized by UNESCO and governmental authorities in this archipelago ( 4 national parks, 11 natural parks, 7 biosphere reserves, 43 terrestrial Special Protection Areas (SPAs), 11 marine SPAs, and 177 Special Areas of Conservation (SACs)). In total, around of $40 \%$ of the islands' surface is protected. Thus, there are densely populated areas with population centers of up to 3700 inhabitants $/ \mathrm{km}^{2}$ (usually located on the coastal strip), and 
other municipalities with densities as low as 7 inhabitants $/ \mathrm{km}^{2}$ (Godenau et al., 2012).

In the context of the Poisoning Control and Prevention Strategy in the Canaries (BOC, 2014), from 2011 to May 2020, the ULPGC Toxicology Laboratory received more than 1300 animal bodies as well as baits and other sample types (containers, soil, plants, etc....) for forensic toxicological evaluations. Of these, 831 animals had georeferenced information about the place where they were found and furthermore, the good state of conservation of the animals allowed the sampling of the liver. Additionally, 78 georeferenced baits were also received. Among the georeferenced animals received, 308 birds of prey stand out, as these were the object of a detailed geographic information system (GIS) analysis in the second part of this study. The series of raptors included individuals from 13 different species/subspecies: Accipiter nisus granti $(\mathrm{n}=9)$; Asio otus canariensis $(\mathrm{n}=68)$; Buteo buteo insularum $(\mathrm{n}=53)$; Circus aeruginosus $(\mathrm{n}=1)$; Falco eleonorae $(\mathrm{n}=$ 4); Falco peregrinus pelegrinoides $(n=13)$; Falco subbuteo $(n=1)$; Falco tinnunculus canariensis $(\mathrm{n}=69)$; Falco tinnunculus dacotiae $(\mathrm{n}=$ 14); Neophron percnopterus majorensis $(\mathrm{n}=67)$; Pandion haliaetus ( $\mathrm{n}$ $=1)$; Tyto alba alba $(\mathrm{n}=5)$; and Tyto alba gracilirostris $(\mathrm{n}=3)$. The animals (and baits) were sent by environmental officers or patrols if found dead, or by wildlife recovery centers if they had been admitted alive but euthanized or death within a week of admission. All carcasses were kept frozen at $-20{ }^{\circ} \mathrm{C}$, until they were necropsied. No animals were sacrificed for the purpose of this study. Whenever possible, the cause of death was determined by clinical examination of the animals, supported by hematological, clinical-pathological, radiological or toxicological analyses, when required and performed by veterinarians at wildlife recovery centers, or by veterinarians assigned to our research center. The main cause of death of the animals, included in this study, was trauma (62,3\% including mainly run over, collision with power lines or wind turbines, shooting, and falling from the nest), as well as intentional or unintentional poisoning (26.4\%). The livers, as the main organ for accumulation and storage of rodenticides, were used for this study, (Dowding et al., 2010). Obtained during the necropsy, they were kept frozen at $-20{ }^{\circ} \mathrm{C}$ until the preparation of the extraction and chemical analysis.

\subsection{Analysis of anticoagulant rodenticides in the liver}

Solvents (acetonitrile and methanol) of the highest purity available were used (>99. 9\%, Honeywell, Morristown, NJ, USA). Ultrapure (UP) water was produced in the laboratory using a Gradient A10 Milli-Q System (Millipore, Molsheim, France). Standards for ARs and a proceduralinternal standard (P-IS, $( \pm)$-Warfarin-d5) were purchased from Dr. Ehrenstorfer (Augsburg, Germany). All standards were pure compounds (purity from 98\% to 99.5\%). Stock solutions of each compound at $1 \mathrm{mg} / \mathrm{ml}$ were prepared in acetonitrile and stored at $-20{ }^{\circ} \mathrm{C}$. From a mixture containing all the rodenticides at $10 \mu \mathrm{g} \mathrm{ml}^{-1}$ each in acetonitrile (ACN), diluted solutions from $0.1 \mathrm{ng} / \mathrm{ml}$ to $500 \mathrm{ng} / \mathrm{ml}$ were prepared and used for calibration curves.

During the period covered by this study, two different methods were used for the analysis of rodenticides, because at the end of 2015, there was a total renewal of the equipment of our research unit. For this reason, both methods are presented:

\subsubsection{Sample preparation and chemical analysis (January 2011 to November 2015)}

Briefly, $2 \mathrm{~g}$ of liver were homogenized with $5 \mathrm{ml}$ of ultrapure water, and $10 \mu \mathrm{l}$ of the P-IS ( $50 \mu \mathrm{g} / \mathrm{ml}$ in acetonitrile) were added. Then, $10 \mathrm{~g}$ of diatomaceous earth and $10 \mathrm{ml}$ of dichloromethane/ethyl acetate/acetone mixture $(50 / 30 / 20, \mathrm{v} / \mathrm{v} / \mathrm{v})$ were added and vigorously agitated for $5 \mathrm{~min}$. Then, the sample was centrifuged at $4000 \mathrm{~g}$, the supernatant was subjected to evaporation under a nitrogen stream, redissolved in acetonitrile, filtered $(0.2 \mu \mathrm{m})$ and subjected to a purification stage consisting of three consecutive freezing and centrifugation steps (mainly for fat removal). The resulting supernatant was used for the quantitative determination of AR, which was performed using a Thermo LC-MS/MS Accela Ultra instrument (Thermo Fisher Scientific Inc., USA). The detailed procedure can be found in Luzardo et al. (2014).

\subsubsection{Sample preparation and chemical analysis (December 2015 to May 2020)}

For the extraction, $1 \mathrm{~g}$ of liver was homogenized with $4 \mathrm{ml}$ of ultrapure water, and from this homogenate $1 \mathrm{ml}$ was taken, to which $10 \mu \mathrm{l}$ of the P-IS were added. In this method a matrix-matched calibration curve was used, so the matrix (chicken or beef liver tested negative for the analytes of interest) was prepared in the same way, but the 1-ml aliquots were fortified to 12 increasing concentrations of the ARs mixture ( 0.1 to $50 \mathrm{ng} / \mathrm{ml}$ ). After this, $2 \mathrm{ml}$ of acidified acetonitrile ( $0,5 \%$ formic acid) were added, shaken vigorously (30 sg), and sonicated for $20 \mathrm{~min}$. After this time, $480 \mathrm{mg}$ of anhydrous magnesium sulphate and $120 \mathrm{mg}$ of sodium acetate were added to each tube and shaken vigorously again $(90 \mathrm{sg}$ ). The samples were centrifuged at $4200 \mathrm{~g}$ for $5 \mathrm{~min}$ at $2{ }^{\circ} \mathrm{C}$ and the supernatant was collected and filtered through $0.2 \mu \mathrm{m}$ (Chromafil PET-20/15, Macherey-Nagel, Düren, Germany) to be used directly for chromatographic analysis, without any additional purification steps. An Agilent 1290 UHPLC (Agilent Technologies, Palo Alto, USA) coupled to an Agilent 6460 triple-quadrupole mass spectrometer was used to separate and detect the analytes. The method was fully validated for liver tissue following the strict recommendations of the guide of Standard Practices for Method Validation in Forensic Toxicology (SWGTOX, 2013). Recoveries were between 80 and 120\% for all the analytes. Chromatographic and acquisition conditions and basic procedural details can be found in Rial-Berriel et al. (2020).

\subsection{Geospatial analysis of the data (GIS analysis)}

The free and open source geographical information system software QGIS Desktop (version 3.12) was used for the spatial analysis of the data. The images were orthorectified and projected to the UTM $28 \mathrm{~N}$ zone based on the WGS84 Geographic Coordinates System. The base map for the location of the farms and the positive/negative raptor cases for AR was the default topographic map of the software (OpenStreetMap), on which the rest of the layers created from the geocoded data were superimposed. The data about the place where the carcass was found were collected by Canary Islands environmental patrols and obtained by GPS tracking. From these data, two vector layers were created, one for animals that tested positive for some AR residue, and another for those that tested negative. The geocoded data of the livestock farms were obtained from the metadata catalogue of the Department of Spatial Data Infrastructure of the Canary Islands Government (https://catalogo.idecanarias.es/geonetwork), and from the register of Canary Islands livestock farms, in order to find out the species farmed, the number of heads and type of farm (intensive or extensive). Due to the lack of data, poultry farms were not included. Regarding the other farms, a selection was made considering only the medium to large size holdings (more than 15 head of cattle or pigs, or more than 40 head of goats and/or sheep). From these data, 3 vectorial layers were created, differentiating each type of livestock: cattle, pigs and goats/sheep. For each of these layers, additional layers were created using the Buffer geoprocessing tool, in order to show the potential areas of influence. Four potential radii $(0.5,1,1.5$ and $2 \mathrm{~km})$ were explored based on the described home range areas for the main species of raptors that inhabit the archipelago (Casagrande et al., 2008; Garcia-Heras et al., 2013; Kenward et al., 2018; Martínez and Zuberogoitia, 2004; Thomsen et al., 2014). Using the vector analysis tools of QGIS, a distance matrix between farms and cases was created. From this matrix, the shortest distance from the place where each carcass was found to the nearest farm was identified. Furthermore, the number of inhabitants (as of 1 January 2017) in the radius of $1.5 \mathrm{~km}^{2}$ around each specimen was also recorded using the plug-in for QGIS available on the Canary Islands 
Institute of Statistics website (https://plugins.qgis.org/plugins/ istacqgis/) as well as the density of inhabitants per $\mathrm{km}^{2}$ of the municipality in which each incident was recorded.

\subsection{Statistical analyses}

All the statistical analyses were done using GraphPad Prism v8.0 (GraphPad Software, CA, USA). The distribution of the variables included in this study was evaluated through Kolmogorov-Smirnov test. The concentration of the ARs and distances included in this study did not follow a normal distribution; therefore, the results, apart from the mean $\pm \mathrm{SD}$, are expressed in terms of the median and range. We employed the Levene's test to check the equality of variance among groups. This was important to know whether to employ nonparametric or parametric tests. The Levene's test was non-significant in all cases $(P>0.05)$, meaning that the requirement of homogeneity was met. Therefore, we preferred to test the statistical differences among groups using nonparametric tests, since these assess the median rather than the mean, which is appropriate given the relatively high number of non-detected values in some groups. Thus, Kruskal-Wallis and MannWhitney $U$ tests were employed for general and pair-wise comparisons, respectively. However, as an additional check, the pair-wise comparisons were also done using the Student's $t$-test after log transformation of the data. For clarity we show the graphs and the results of nonparametric analyses in the main body of the article, and only one example of the analysis with transformed data in the supplementary material. P value of less than 0.05 (two-tailed) was considered to be statistically significant. Spearman's rank correlation coefficient was employed to study the statistical dependence between the ranking of minordistance-to-farm and $\sum A R$ of each animal, either for the whole series or for each of the species with more than 50 individuals separately.

The prevalence of AR exposure for each species was calculated as the percentage of animals with, at least, one residue detected in the liver. The variable response considered for the comparisons was the presence of $\sum$ ARs in the liver $(0 / 1)$. In the analyses of the positive cases, the use of a cut-off value for $\sum$ ARs of $200 \mathrm{ng} / \mathrm{g}$ was also considered, since this value has been proposed as the threshold for serious toxic effects of ARs in some species (Thomas et al., 2011).

\section{Results and discussion}

3.1. Incidence of anticoagulant rodenticides in non-target animals of the Canary Islands: reptiles, mammals and non-raptor birds

\subsubsection{Reptiles}

It is striking that the highest levels of AR were found in reptiles, and that the only residue detected in these animals was brodifacoum. The possible reason for these high levels was that, according the forensic evidences collected from the cases, all the reptiles that tested positive $(\mathrm{n}=23$, Table 1$)$ were the target of intentional poisoning. High concentrations of brodifacoum were detected in baits found close to the carcasses in 4 incidents (involving 18 out of the 23 lizards). However, none of these reptiles seemed to die as consequence of the exposure to brodifacoum, whose concentrations were much lower than those of other toxic chemicals also found in the carcasses and baits (the banned carbamates methomyl, carbofuran and aldicarb). All the positive reptiles were species of giant lizards, endemic to the Canary Islands (Gallotia spp.). Despite being protected species, these lizards are unwanted by a great number of farmers as they, in their search for water, eat the cultivated vegetables. Although the placement of drinking troughs would be the most effective way to minimize the damage they cause, these farmers consider their removal as more effective, which has put all these species in critical danger of extinction (BOE, 2010).

\subsubsection{Mammals}

After lizards, the next class in which we find the highest levels of ARs are mammals, with high or very high levels of brodifacoum, bromadiolone and difenacoum detected in many of the animals. It should be noted that, there are few species of wild mammals in the Canary Islands, they are small in size (shrews ( 2 species) and bats (7 species)), and on very rare occasions they are referred to our laboratory service for diagnosis of poisoning. Thus, the big majority of mammals that we have analyzed are dogs (mainly hunting or surveillance dogs), Moorish hedgehogs and feral cats. Most of them had also been target of intentional poisoning, in which rodenticides were part of a cocktail of substances that usually includes agricultural insecticides (carbofuran, aldicarb, chlorpyrifos...), as previously reported (Ruiz-Suarez et al., 2015). Just as we did with the lizards, we also analyzed numerous baits collected in connection with these incidents, and ARs were detected in 8 of them. In fact, in $19.2 \%$ of the baits analyzed in this research, ARs were detected.

The pattern exposure to ARs in the Canary Islands is mainly linked to the intentionality in poisonings, which coincides with what has been also described in this archipelago for other pesticides (Ruiz-Suarez et al., 2015), and for other non-anticoagulant rodenticides elsewhere (Bishop et al., 2016). However, this pattern differs considerably from that described by other authors for reptiles (Elliott et al., 2014; Johnston et al., 2005; Nakayama et al., 2019) and mammals (Alabau et al., 2020; Nakayama et al., 2019), and moreover, from the main objective of this work that focuses on secondary exposure, we decided to discard the specimens of these two classes, as well as the baits, for further analyses in this research.

\subsubsection{Non-raptor birds}

First, we compared the frequency, the concentrations and the number of ARs found in nonpredatory birds $(n=343)$ versus those of raptors $(\mathrm{n}=308$ ), and we found big differences between them (Fig. 1). ARs were detected in $4.7 \%$ of nonpredatory birds $(n=16)$ compared to almost $60 \%$ of raptors $(n=176)$, which also almost quadrupled the median concentration value of $\sum$ ARs (Fig. 1). Moreover, the mean number ARs per individual differs significantly between both types of birds ( 2.15 vs. 1.1 in raptors and non-raptors, respectively, $\mathrm{P}<0$. 001 ). These results contrast with the data reported by other authors with much higher frequencies of AR detection in non-raptor birds, even exceeding $50 \%$ of the animals analyzed (Eason et al., 2002; Lopez-Perea et al., 2019; Nakayama et al., 2019; Sanchez-Barbudo et al., 2012) but resemble those reported by other authors, mainly in waterbird studies (Lambert et al., 2007).

Table 1

Incidence and concentrations in liver of the anticoagulant rodenticides detected during investigation of the crimes against wildlife flora and fauna in the Canary Islands (2011-2020).

\begin{tabular}{|c|c|c|c|c|c|c|c|c|c|c|c|c|c|c|c|}
\hline & \multicolumn{3}{|c|}{$\begin{array}{l}\text { Mammals } \\
(\mathrm{n}=118)\end{array}$} & \multicolumn{3}{|c|}{$\begin{array}{l}\text { Reptiles } \\
(\mathrm{n}=62)\end{array}$} & \multicolumn{3}{|c|}{$\begin{array}{l}\text { Birds (non-raptors) } \\
(\mathrm{n}=343)\end{array}$} & \multicolumn{3}{|c|}{$\begin{array}{l}\text { Birds (raptors) } \\
(\mathrm{n}=308)\end{array}$} & \multicolumn{3}{|c|}{$\begin{array}{l}\text { Baits and other evidences } \\
(\mathrm{n}=78)\end{array}$} \\
\hline & $\begin{array}{l}\text { Freq } \\
(\%)\end{array}$ & $\begin{array}{l}\text { Med } \\
(\mathrm{ng} / \mathrm{g})\end{array}$ & Range & $\begin{array}{l}\text { Freq } \\
(\%)\end{array}$ & $\begin{array}{l}\text { Med } \\
(\mathrm{ng} / \mathrm{g})\end{array}$ & Range & $\begin{array}{l}\text { Freq } \\
(\%)\end{array}$ & $\begin{array}{l}\text { Med } \\
(\mathrm{ng} / \mathrm{g})\end{array}$ & Range & $\begin{array}{l}\text { Freq } \\
(\%)\end{array}$ & $\begin{array}{l}\text { Med } \\
(\mathrm{ng} / \mathrm{g})\end{array}$ & Range & $\begin{array}{l}\text { Freq } \\
(\%)\end{array}$ & $\begin{array}{l}\text { Med } \\
(\mathrm{ng} / \mathrm{g})\end{array}$ & Range \\
\hline Brodifacoum & 7.1 & 108.7 & $8.7-1181$ & 62.7 & 526.3 & $118.3-934.2$ & 3.9 & 4.4 & $1.1-65.7$ & 48.7 & 23.8 & $0.2-1174$ & 6.4 & 15,409 & $880-149,877$ \\
\hline Bromadiolone & 10.1 & 182.1 & $2.1-1571$ & - & - & - & 2.5 & 13.6 & $0.9-32.1$ & 41.3 & 30.6 & $0.2-4840$ & 8.9 & 9900 & $317-15,540$ \\
\hline Difenacoum & 2.0 & 158.0 & $4.5-311.5$ & - & - & - & 1.1 & 23.0 & $1.7-56.0$ & 17.8 & 3.9 & $0.1-73.4$ & 5.1 & 1465 & $730-21,567$ \\
\hline Difetialone & 1.0 & 1.3 & - & - & - & - & - & - & - & 1.4 & 1.8 & $0.5-29.2$ & - & - & - \\
\hline Flocoumafen & - & - & - & - & - & - & - & - & - & 3.9 & 0.9 & $0.2-127.7$ & - & - & - \\
\hline
\end{tabular}




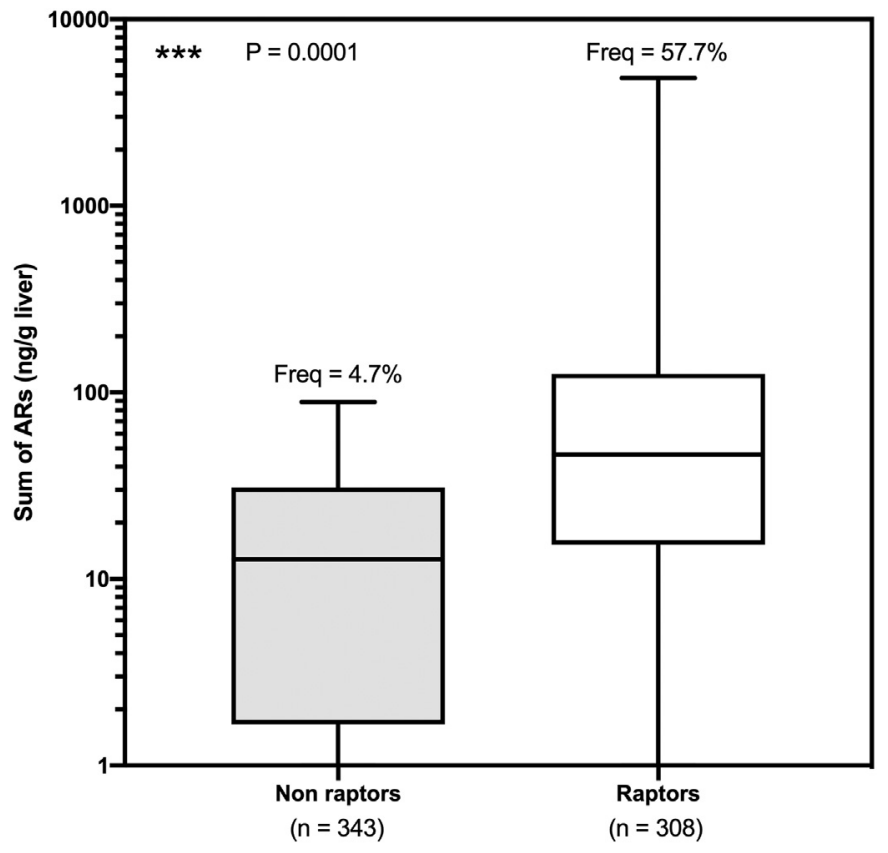

Fig. 1. Box and whiskers graph showing the comparison of anticoagulant rodenticides in the liver between wild birds ( 343 non-raptors vs. 308 raptors) (2011-2020). The lines show the medians, the boxes cover the 25th to 75th percentiles, and the minimal and maximal values are shown by the ends of the bars. The frequencies of positive cases are indicated for each group.

Among the non-predatory birds, the most affected was the Canary raven (Corvus corax canariensis, $\mathrm{n}=7$ ). Even so, in relation to the total number of individuals of this species that we have analyzed, the frequency of detection was low $(7 / 97,7.2 \%)$, and it does not coincide with what has been published by other authors who indicate that the common raven is one of the most vulnerable species to both primary and secondary AR exposure (Howald et al., 1999). This could be due to the fact that, unlike the continental species, in the diet of the canary raven the plant component predominates (Nogales and Nieves, 2007). Of the 7 cases of Canary ravens with ARs, 6 were animals that were poisoned after ingesting baits prepared with several toxic substances simultaneously, including ARs. The Canary raven is one of the most threatened species of the archipelago, catalogued as critically endangered (BOE, 2010), and a recent count has confirmed a previous estimate indicating that no more than 400 nesting pairs remain (Nogales and Nieves, 2007). Thus, our results are very relevant, as AR exposure appears as a significant threat to the conservation of this species.

The rest of the non-predatory birds that presented ARs were grey herons (Ardea cinerea, $\mathrm{n}=2$ ), stone-curlews (Burhinus oedicnemus distinctus, $\mathrm{n}=3$ ), European turtle doves (Streptopelia turtur, $\mathrm{n}=2$ ), and blackbirds (Turdus merula cabrerae, $\mathrm{n}=2$ ). In these last 4 birds, the consumption of poisoned bait was also found to be the primary cause of death, according the forensic evidences.

Taken together, our results indicate that in addition to the low incidence of ARs in nonpredatory birds, in most cases their appearance was clearly related to the intentional placement of toxic baits.

\subsection{Incidence of anticoagulant rodenticides in non-target animals of the Canary Islands: birds of prey}

We studied the frequencies and concentrations of ARs among the different species of raptors in the archipelago (Table 2). Only in 3 species we did not detect ARs, although it should also be noted that only one individual was received from each of them (Pandion haliaetus, Falco subbuteo, and Circus aeruginosus). Only 5 compounds were detected, and all of them from the SGAR group, which were, in order of frequency: brodifacoum, bromadiolone, difenacoum, flocoumafen and difethialone (Fig. 2). This is the same order that has been published in the most recent review of the ARs incidence in non-target animals (Nakayama et al., 2019).

The most frequently affected species were nocturnal raptors (represented in our series by three subspecies, Asio otus canariensis, Tyto alba alba and Tyto alba gracilirostris) (Supplementary Fig. 1). This high frequency of detection in nocturnal raptors coincides with that reported by other authors (Albert et al., 2010; Christensen et al., 2012; Lambert et al., 2007; Lopez-Perea et al., 2015; Sanchez-Barbudo et al., 2012; Stone et al., 2003) and also in the Canary Islands (Ruiz-Suarez et al., 2014), and is particularly worrisome since owls seem to have a deficiency in the metabolic activity of AR detoxification, which makes the half-life of these compounds longer in them than in other species of birds of prey (Rattner et al., 2014). Therefore, anthropogenic environments such as livestock farms could provide excellent feeding opportunities (Geduhn et al., 2016) and might also become ecological traps for them (Lopez-Perea et al., 2019). In the long-eared owl (Asio otus

Table 2

Concentrations of the anticoagulant rodenticides detected in liver by raptor species.

\begin{tabular}{|c|c|c|c|c|c|c|c|c|c|c|c|c|c|c|c|c|}
\hline \multirow[b]{2}{*}{ Species $^{\mathrm{a}}$} & \multirow[b]{2}{*}{$\begin{array}{l}\text { Positives/no. } \\
\text { animals }\end{array}$} & \multicolumn{3}{|c|}{ Brodifacoum } & \multicolumn{3}{|c|}{ Bromadiolone } & \multicolumn{3}{|c|}{ Difenacoum } & \multicolumn{3}{|c|}{ Difethialone } & \multicolumn{3}{|c|}{ Flocoumafen } \\
\hline & & $\begin{array}{l}\text { Freq } \\
(\%)\end{array}$ & $\begin{array}{l}\text { Med } \\
(\mathrm{ng} / \mathrm{g})\end{array}$ & Range & $\begin{array}{l}\text { Freq } \\
(\%)\end{array}$ & $\begin{array}{l}\text { Med } \\
(\mathrm{ng} / \mathrm{g})\end{array}$ & Range & $\begin{array}{l}\text { Freq } \\
(\%)\end{array}$ & $\begin{array}{l}\text { Med } \\
(\mathrm{ng} / \mathrm{g})\end{array}$ & Range & $\begin{array}{l}\text { Freq } \\
(\%)\end{array}$ & $\begin{array}{l}\text { Med } \\
(\mathrm{ng} / \mathrm{g})\end{array}$ & Range & $\begin{array}{l}\text { Freq } \\
(\%)\end{array}$ & $\begin{array}{l}\text { Med } \\
(\mathrm{ng} / \mathrm{g})\end{array}$ & Range \\
\hline $\begin{array}{l}\text { Accipiter nisus } \\
\text { granti }\end{array}$ & $\begin{array}{l}5 / 9 \\
(55.6 \%)\end{array}$ & $55.5 \%$ & 20.9 & $5.8-400.0$ & $25 \%$ & 1.5 & $0.2-2.8$ & $25 \%$ & 0.6 & $0.4-0.8$ & - & - & - & $11.5 \%$ & 0.22 & - \\
\hline $\begin{array}{l}\text { Asio otus } \\
\text { canariensis }\end{array}$ & $\begin{array}{l}51 / 68 \\
(75.0 \%)\end{array}$ & $68.2 \%$ & 23.8 & $2.1-240.0$ & $44.4 \%$ & 10.3 & $0.8-512.8$ & $28.6 \%$ & 3.7 & $0.7-73.4$ & $3.2 \%$ & 14.8 & $0.5-29.2$ & $13.1 \%$ & 0.9 & $0.3-4.8$ \\
\hline $\begin{array}{l}\text { Buteo buteo } \\
\text { insularum }\end{array}$ & $\begin{array}{l}33 / 53 \\
(62.3 \%)\end{array}$ & $62.3 \%$ & 14.6 & $2.5-796.6$ & $55.8 \%$ & 33.7 & $1.3-187.6$ & $20.9 \%$ & 12.1 & $1.7-47.9$ & - & - & - & $2.3 \%$ & 12.7 & - \\
\hline Falco eleonorae & $\begin{array}{l}2 / 4 \\
(50.0 \%)\end{array}$ & $50.0 \%$ & 1.5 & $0.6-2.4$ & $33.3 \%$ & 0.4 & - & - & - & - & - & - & - & - & - & - \\
\hline $\begin{array}{c}\text { Falco peregrinus } \\
\text { pelegrinoides }\end{array}$ & $\begin{array}{l}6 / 13 \\
(46.2 \%)\end{array}$ & $46.2 \%$ & 6.0 & $1.2-26.2$ & $25.0 \%$ & 7.4 & $5.0-36.2$ & - & - & - & - & - & - & - & - & - \\
\hline $\begin{array}{l}\text { Falco tinnunculus } \\
\text { (canariensis and } \\
\text { dacotiae) }\end{array}$ & $\begin{array}{l}53 / 83 \\
(63.9 \%)\end{array}$ & $63.9 \%$ & 44.2 & $1.4-1174.0$ & $58.3 \%$ & 45.3 & $2.6-4840.3$ & $22.2 \%$ & 4.5 & $1.2-33.4$ & $1.4 \%$ & 2.4 & - & $2.8 \%$ & 5.6 & $0.5-10.8$ \\
\hline $\begin{array}{l}\text { Neophron } \\
\quad \text { percnopterus } \\
\text { majorensis }\end{array}$ & $\begin{array}{l}20 / 67 \\
(29.9 \%)\end{array}$ & $29.9 \%$ & 33.4 & $9.3-176.5$ & $20.0 \%$ & 33.2 & $2.8-112.5$ & $4.6 \%$ & 12.4 & $2.7-21.1$ & - & - & - & - & - & - \\
\hline $\begin{array}{l}\text { Tyto alba (alba and } \\
\text { gracilirostris) }\end{array}$ & $\begin{array}{l}7 / 8 \\
(87.5 \%)\end{array}$ & $87.5 \%$ & 7.9 & $0.2-119.7$ & $42.8 \%$ & 1.6 & $0.2-33.4$ & $28.6 \%$ & 7.8 & $0.1-15.6$ & $14.3 \%$ & 1.6 & - & - & - & - \\
\hline
\end{tabular}

a Additionally, the series of raptors included 1 individual of each one of the three species, Pandion haliaetus, Falco subbuteo, and Circus aeruginosus, but anticoagulant rodenticides were not detected in the liver of any of them. 


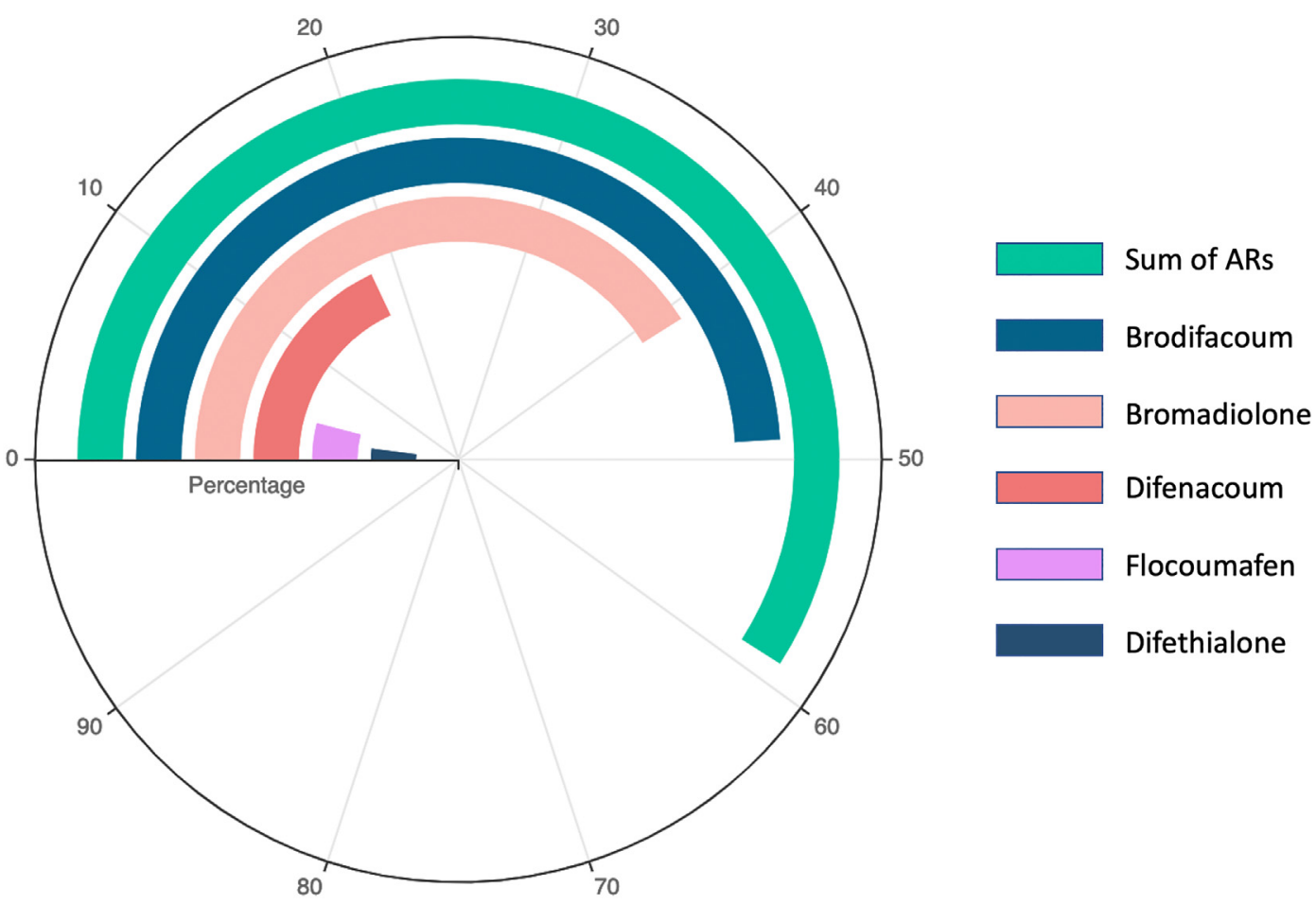

Fig. 2. Frequencies of anticoagulant rodenticides in raptor livers.

canariensis), the high frequency of detection of brodifacoum, which almost reached $70 \%$ of individuals, is also noteworthy, as well as the higher frequency of detection of flocoumafen of all the birds of prey included in this study (13\%) (Fig. 3).
However, the highest concentrations were not found in these nocturnal species, but in common kestrels (Falco tinnunculus, median value $\sum \mathrm{AR}=102.4 \mathrm{ng} / \mathrm{g}$ (median $\left.768.4 \mathrm{ng} / \mathrm{g}\right)$ ). In fact, of the 60 animals with levels $\sum A R>100 \mathrm{ng} / \mathrm{g}$ of the entire raptor series, $43.3 \%$

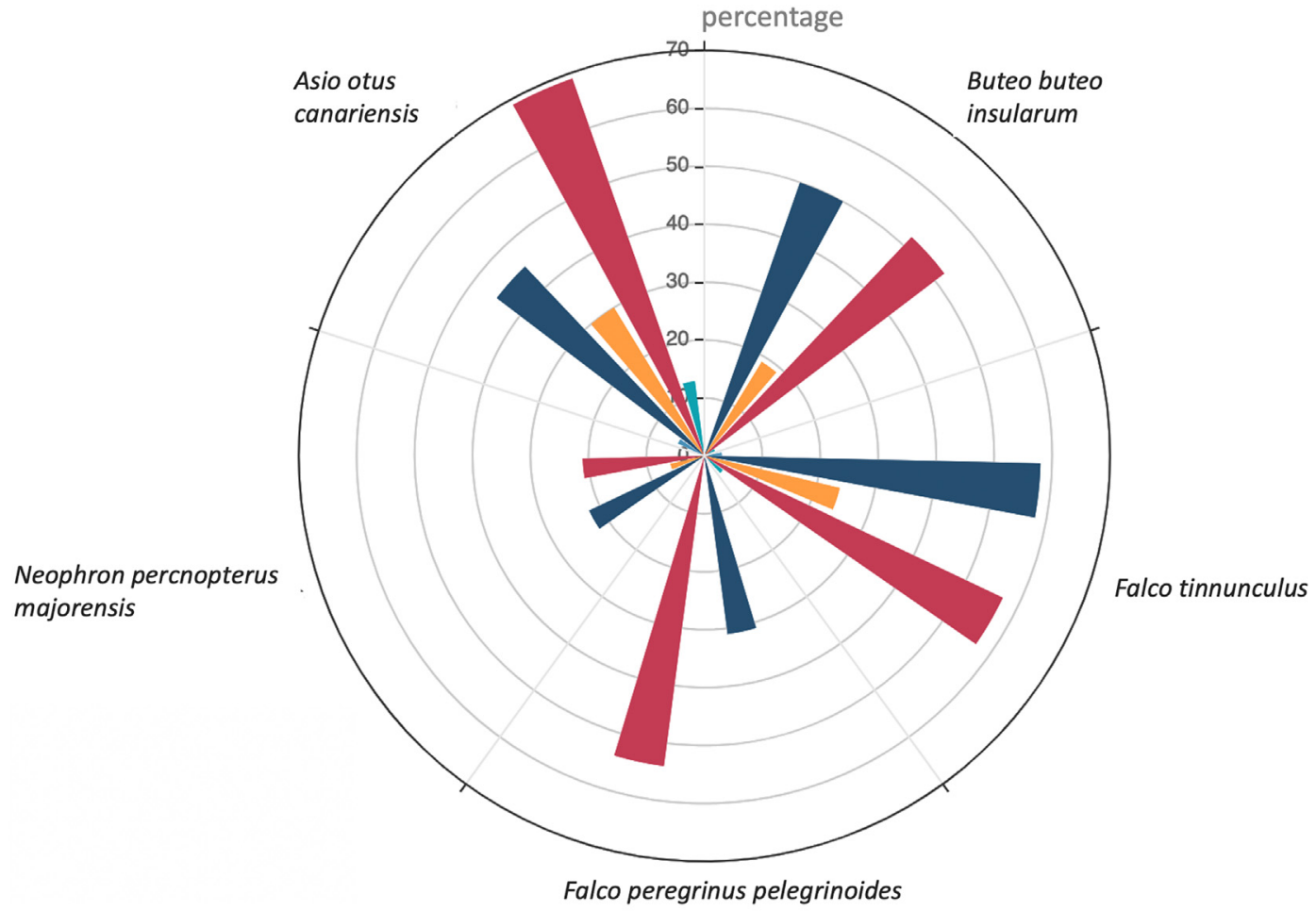


were kestrels. This percentage rises to $68 \%$ in the case of raptors with more than $200 \mathrm{ng} / \mathrm{g}$ of $\sum \mathrm{AR}$ in the liver. In common kestrels, the most frequently detected compounds were brodifacoum and bromadiolone, both present simultaneously in most of the specimens (Fig. 3). Our results are consistent with those preliminarily reported in the Canary Islands (Ruiz-Suarez et al., 2014), and remain among the highest values reported for this species, similar to those described in the UK (Walker et al., 2013), but much lower than those reported in most of the available studies for this species (Christensen et al., 2012; Hughes et al., 2013; Lambert et al., 2007; Nakayama et al., 2019). Two out of the eleven subspecies of Falco tinnunculus known in the world are endemic to the Canary Islands, Falco tinnunculus canariensis and Falco tinnunculus dacotiae. No differences in the level of exposure to ARs were found between them. It has been established that the diet of both subspecies depends on the nesting area (Carrillo et al., 1994). In the Canary Islands, kestrels feed mainly on medium to large sized insects and small reptiles, but for individuals living in anthropogenic environments, it has been proven that mice can be an important part of their diet (Mus spp. would contribute up to $38 \%$ of the food biomass) (Carrillo et al., 2017; Carrillo et al., 1994). Therefore, as described in other areas, rodenticides (and other pesticides) would represent one of the main threats to the conservation of these subspecies (Buck et al., 2020; Mateo et al., 2000).

In common buzzards, ARs were frequently detected (mainly brodifacoum and bromadiolone, $>50 \%$ of individuals, Table 2 and Fig. 3) and at moderately high concentrations (median $\sum \mathrm{AR}=$ $50.7 \mathrm{ng} / \mathrm{g}$ ). Buzzards are represented in the Canary Islands by an endemic subspecies (Buteo buteo insularum). These concentrations are higher than those previously reported in the Canary Islands for this species (Ruiz-Suarez et al., 2014), although only 9 individuals were included in that study. The values we report here are very similar to those described in most of the studies available in the literature (Christensen et al., 2012; Hughes et al., 2013; Lambert et al., 2007; Lopez-Perea et al., 2015; Sanchez-Barbudo et al., 2012). The current report of exposure in 53 specimens is significant since this species has recently been identified as one of the key sentinel species for biomonitoring studies of contaminants at a pan-European level (Badry et al., 2020).

At the other extreme, as a species with a lower frequency of AR detection, we find the Egyptian Vulture (represented in the Canary Islands by a subspecies, Neophron percnopterus majorensis), with the high frequency of detection of brodifacoum being striking (Fig. 3). This is the only vulture in the archipelago, and similarly to what is described for other species of vultures on the continent; it is occasionally exposed to ARs and other agricultural pesticides, mainly to secondary exposure by ingesting the livers of the carrion on which they feed. The frequency of detection of ARs in these Egyptian Vultures was 29.2\% (19 positives out of 65 specimens examined), which is similar to that described in the few studies available on exposure of vultures to ARs (Berny et al., 2015; Plaza et al., 2019; Sanchez-Barbudo et al., 2012).

Finally, we highlight the case of the Barbary Falcon (Falco peregrinus pelegrinoides) and Eleonora's Falcon (Falco eleonorae), as these were the species in which, although frequently detected, the concentrations of ARs were the lowest. In both species, brodifacoum was the main compound detected (Fig. 3). The Barbary Falcon is one of the least recorded birds of prey of Europe. It is known to feed mainly on pigeons and other medium-sized bird species (Rodríguez and Silverio, 2007). Given the almost null incidence of ARs that we have detected in the prey birds of the Barbary Falcon that we have analyzed throughout this decade, these results seem logical, with an average value for the $\sum A R=3.8 \mathrm{ng} / \mathrm{g}$. Similarly, the Eleonora's Falcon (Falco eleonorae) also shown very low levels of ARs. Eleonora's Falcon is an uncommon bird species in the Canary Islands, with a population of only about 300 nesting pairs. They prey mainly on migrating small passeriform birds, but also on medium-size insects. Basing on their habitat and diet, the low levels of ARs detected seems very logical. However, in this decade we have only received 4 specimens, therefore no very firm conclusions can be drawn from the level of exposure of this species. Of these last two species (Falco peregrinus pelegrinoides and Falco eleonorae) the results we present are, as far as we know, the first reported in the world.

The results of the species with more than 10 specimens analyzed have been represented graphically in Supplementary Fig. 2, where the great differences in concentration found among them can be seen.

\subsection{Temporal trend of the presence of anticoagulants in predatory birds}

The temporal evolution of the cases of birds of prey received in our service since 2011, as well as the percentage of birds that tested positive for ARs were studied (Fig. 4). After irregular operation of the Poisoning Control and Prevention Strategy in the Canaries (BOC, 2014) in the early years, from 2016 onwards we have been receiving more and more cases, although the percentage of positive cases to ARs each year is around $60 \%$ with no clear trend, neither increasing nor decreasing. The increase in cases, not only of birds of prey, but of wildlife in general is very evident since 2017, mainly due to the higher degree of specialization of environmental officers, and above all due to the use of the first specialized anti-poison dog unit in the archipelago. It should be noted that in 2020, until May when we decided to stop the inclusion of cases for this study, we have already received more cases than the previous year. Our estimate is that by the end of this year, we could exceed 250 birds of prey tested, even considering the difficulties due to the COVID-19 pandemic. One reason for this could be that a second unit of anti-poison dogs began operating in the archipelago at the end of 2019.

With respect to the concentrations found, we divided the series into two groups, with the cases received before and after May 2018 (Fig. 5), since it was on that date that the reclassification of products formulated with anticoagulant active substances with concentrations equal to or greater than $30 \mathrm{ppm}$ as reprotoxic compounds was made mandatory (Frankova et al., 2019). This reclassification led to significant restrictions with respect to its application and sale, with the result that the vast majority of baits applied since then are $30 \mathrm{ppm}$ or below. Consequently, we wanted to see if the average concentrations in non-target fauna decreased. This seems to be the case, with significantly lower values ( $P$ $<0.001$ ) in the cases after May 2018 (Fig. 5). However, the opposite occurred with the average number of ARs per animal (Fig. 5, inset). Although there is evidence that baits with $<30 \mathrm{ppm}$ are just as effective as the more concentrated ones (50 ppm or more) (Frankova et al., 2019), this result could indicate that the simultaneous use of baits with different active ingredients to "ensure effectiveness" has increased.

\subsection{GIS analysis}

There are some works of spatial analysis of the exposure of raptors to ARs, which explore the influence of different stressors (Hindmarch et al., 2017). In this research we focused the GIS analysis only on the 308 raptors, to try to elucidate whether the application of rodenticides on livestock farms, mostly by farmers themselves in our archipelago, could play a role in the exposure of birds of prey to these compounds.

From the mere visual observation of the geolocated positive/negative cases on the map of the archipelago, everything seemed to indicate that the majority of positive cases were grouped near the areas of greatest density of farms (an example is shown Supplementary Fig. 3 showing Gran Canaria island). In the supporting article in Data in Brief "Dataset on the concentrations of anticoagulant rodenticides in raptors from the Canary Islands with geographic information", we provide the exact location of each case, the distance to the nearest farm (and the type of livestock), the island by island and species by species analyses, and the concentrations of the ARs found in each individual.

It was necessary to obtain the exact distances, for which a matrix of distances between all points (cases and farms) was obtained, selecting the shortest case-farm distance. Spearman's correlation analysis of these data pairs indicated a significant value of $-0.5657(\mathrm{P}<0.0001)$, 


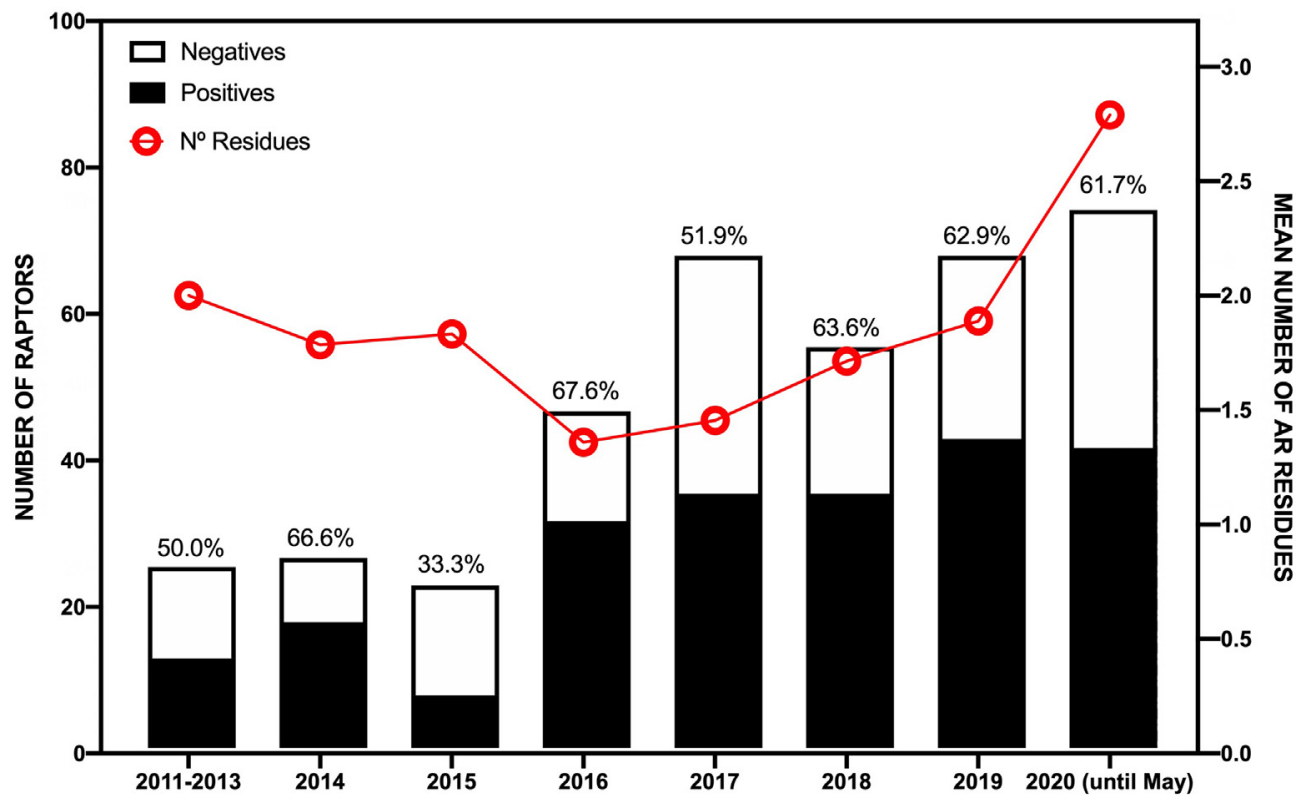

Fig. 4. Temporal trend of positive/negative for anticoagulant rodenticides cases (left Y-axis), and of the mean number of ARs per animal (right Y-axis).

indicating that, the greater the distance from the animal to the nearest farm, the lower the concentration of $\sum$ AR (Fig. 6). The significant Spearman's inverse correlation was maintained when we analyzed the

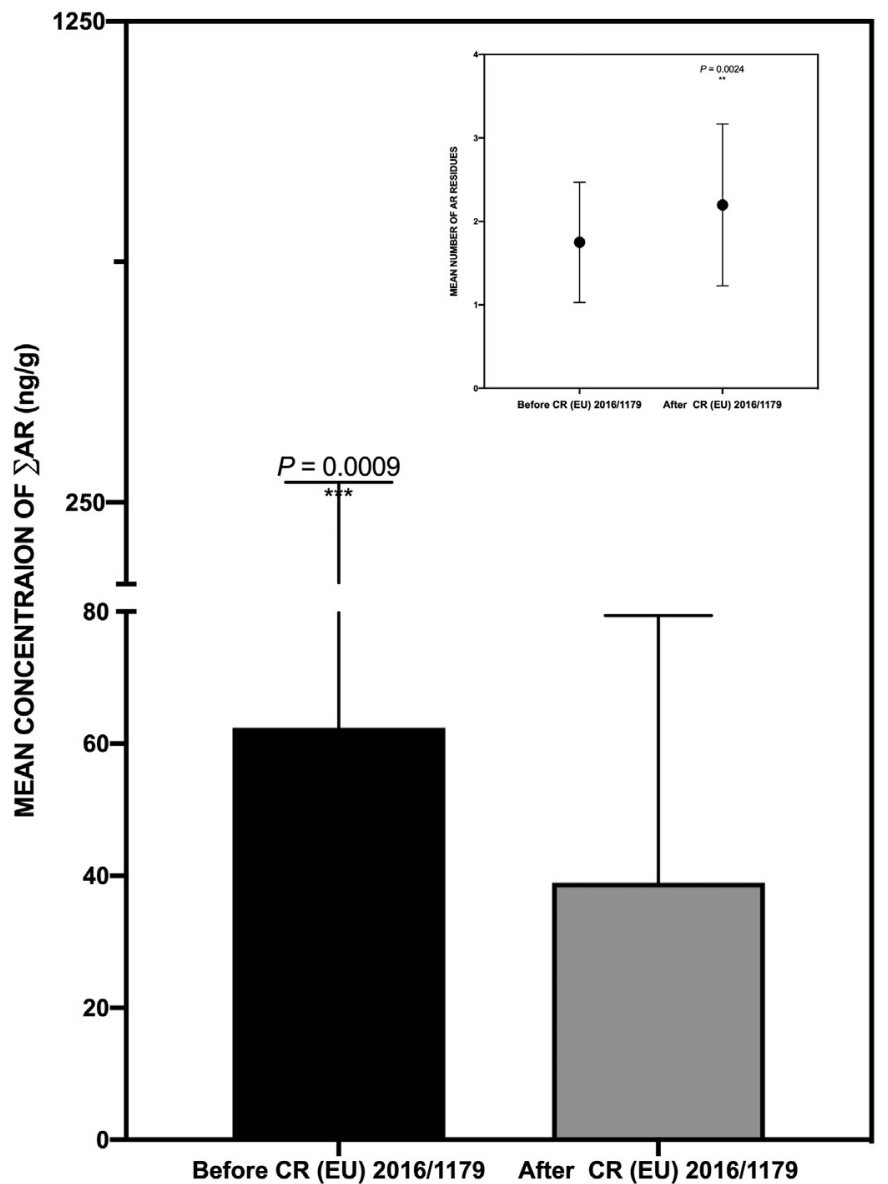

Fig. 5. Mean concentrations of the sum of anticoagulant rodenticides in the liver of raptors found before and after May 2018, which is the date of entry into force of EC (EU) 2016/ 1179 setting a maximum content of 30 ppm of active substance in rodenticide baits; (Insert) Mean \pm SD of number of ARs per animal before and after May 2018. species with the highest number of individuals separately (Falco tinnunculus, Spearman's $r-0.5451, \mathrm{P}<0.0001$; Buteo buteo, Spearman's $\mathrm{r}-0.5094, \mathrm{P}<0.0001$; Asio otus canariensis, Spearman's $\mathrm{r}-0.4855, \mathrm{P}<$ 0.0001; Neophron percnopterus majorensis, Spearman's $\mathrm{r}-0.5682, \mathrm{P}<$ 0.0001 ).

Although information is scarce on many of the Canarian raptor subspecies, we took into consideration the home-range areas described in other regions for the main species of raptors included in this study (Casagrande et al., 2008; Garcia-Heras et al., 2013; Kenward et al., 2018; Martínez and Zuberogoitia, 2004; Thomsen et al., 2014), and according to this we divided the data series in two groups, individuals that were found at greater or lesser distance from the nearest farm to the chosen cut-off point $(0.5,1,1.5$, and $2 \mathrm{~km})$. In all cases we found

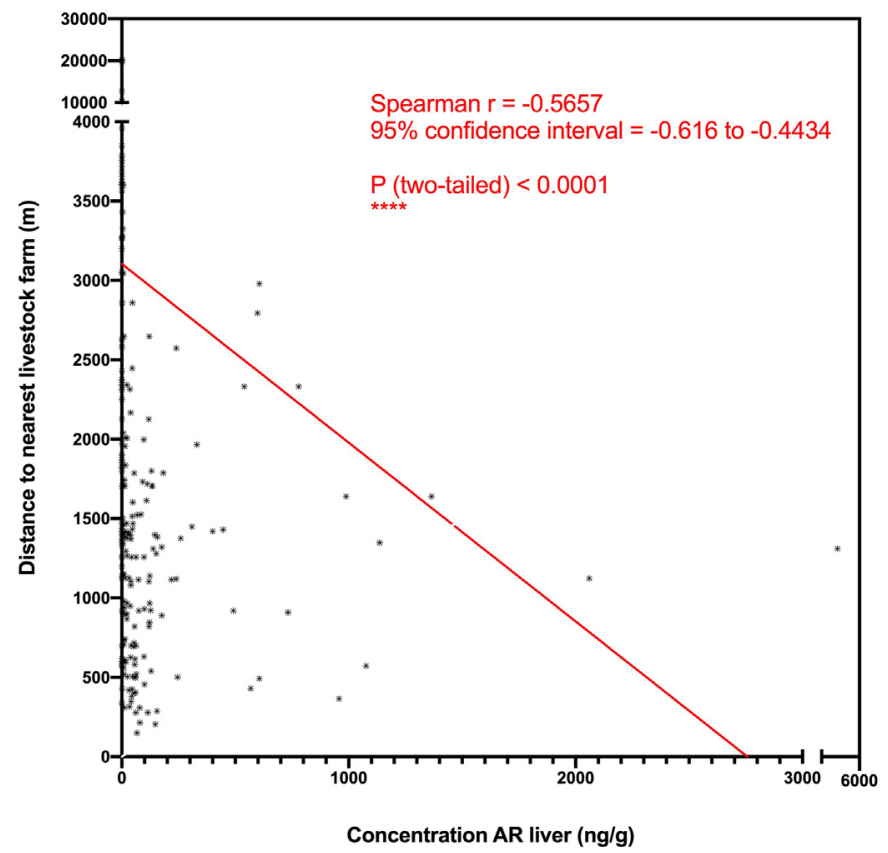

Fig. 6. Scatterplot and Spearman's correlation coefficient of the shortest distance the cases of raptors analyzed to the nearest farm and the concentration in liver of the sum of anticoagulant rodenticides of the cases (ng/g). 


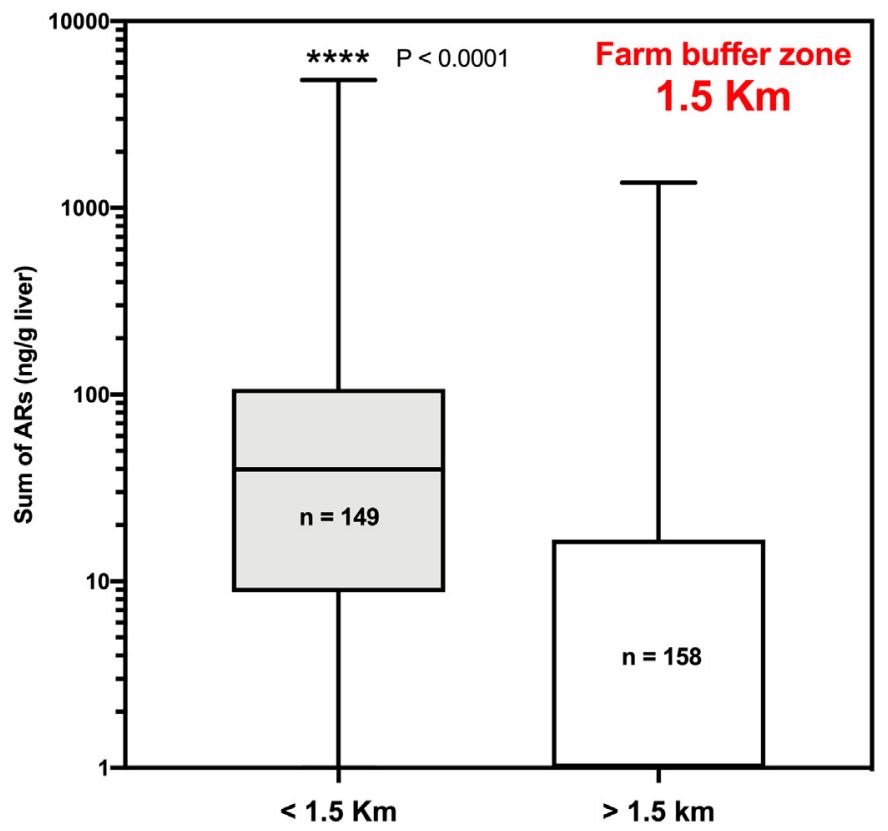

Fig. 7. Box and whiskers graph showing the comparison of anticoagulant rodenticides in the liver between those animals found less or more than $1.5 \mathrm{~km}$ from the nearest livestock farm. The lines show the medians, the boxes cover the 25th to 75th percentiles, and the minimal and maximal values are shown by the ends of the bars.

that the concentrations of the group of animals found closer to the farms were significantly higher than those found further away (Fig. 7 for a buffer of $1.5 \mathrm{~km}$, Supplementary Fig. 3 for the analysis with the log transformed data for a buffer of $1.5 \mathrm{~km}$, and Supplementary Fig. 4 for the rest of buffer zones). When we analyzed the farms separated by type of livestock, we found that the association with distance was maintained for farms that are dedicated to intensive production (pigs and cattle), whereas it was lost in those dedicated to extensive or more traditional production in the Canary Islands (sheep/goats) (Supplementary Fig. 5).

Finally, since human population density is considered to be another determining factor for AR, we subdivided again the series of birds into two groups, those sampled in municipalities with a low population density from those with a high density. The cut-off point was chosen based on the median of the population density distribution of the municipalities of the archipelago (120 inhabitants $/ \mathrm{km}^{2}$ ). The relationship with the distance near the farms remains significant in both cases (Fig. 8). In addition, using the Canary Islands population density GIS layer, the number of inhabitants within $1.5 \mathrm{~km}^{2}$ around the sampling location of each bird was calculated, and the results ( $\mathrm{n}^{\circ}$ inhabitants/case) of the series of positive cases ( 1 or more AR detected) were compared with those of the series of negative cases. The difference was not statistically significant (Mann-Whitney $U$ test). Although the secondary effects of anticoagulant exposure of non-target wildlife in human-dominated environments has been widely studied (Hong et al., 2019; Lopez-Perea et al., 2019; Quinn et al., 2012; Serieys et al., 2018), the distorting effect of population density on the results observed in this study could be ruled out.

\section{Conclusions}

This study reports incidence data of anticoagulant rodenticides in non-target species in the Canary Islands during the last decade. The high incidence of these compounds in birds of prey, particularly brodifacoum and bromadiolone, with about $60 \%$ of the birds of prey containing one or more ARs, is noteworthy. Since the entry into force of the restriction on the concentration of active ingredient in baits $(<30 \mathrm{ppm})$, a decrease in the concentrations of these compounds in the liver has been detected, but also, conversely, an increase in the average number of ARs per animal.

From the GIS study, it can be deduced that intensive farms are a major determinant in the exposure of birds of prey to SGARs, and that those birds that opportunistically nest around intensive production farms are susceptible to be significantly more exposed than those of birds that live far from facilities of this type.

The results of this study should be taken into consideration by the authorities, with a view to restricting the free distribution and nonprofessional use of ARs, particularly the SGARs. In addition, they should implement education and awareness campaigns on the consequences of the uncontrolled application of rodenticides on the unique biodiversity of the Canary Islands, as well as promote the replacement of

\section{Municipalities with high population density}

\section{Municipalities with low population density}
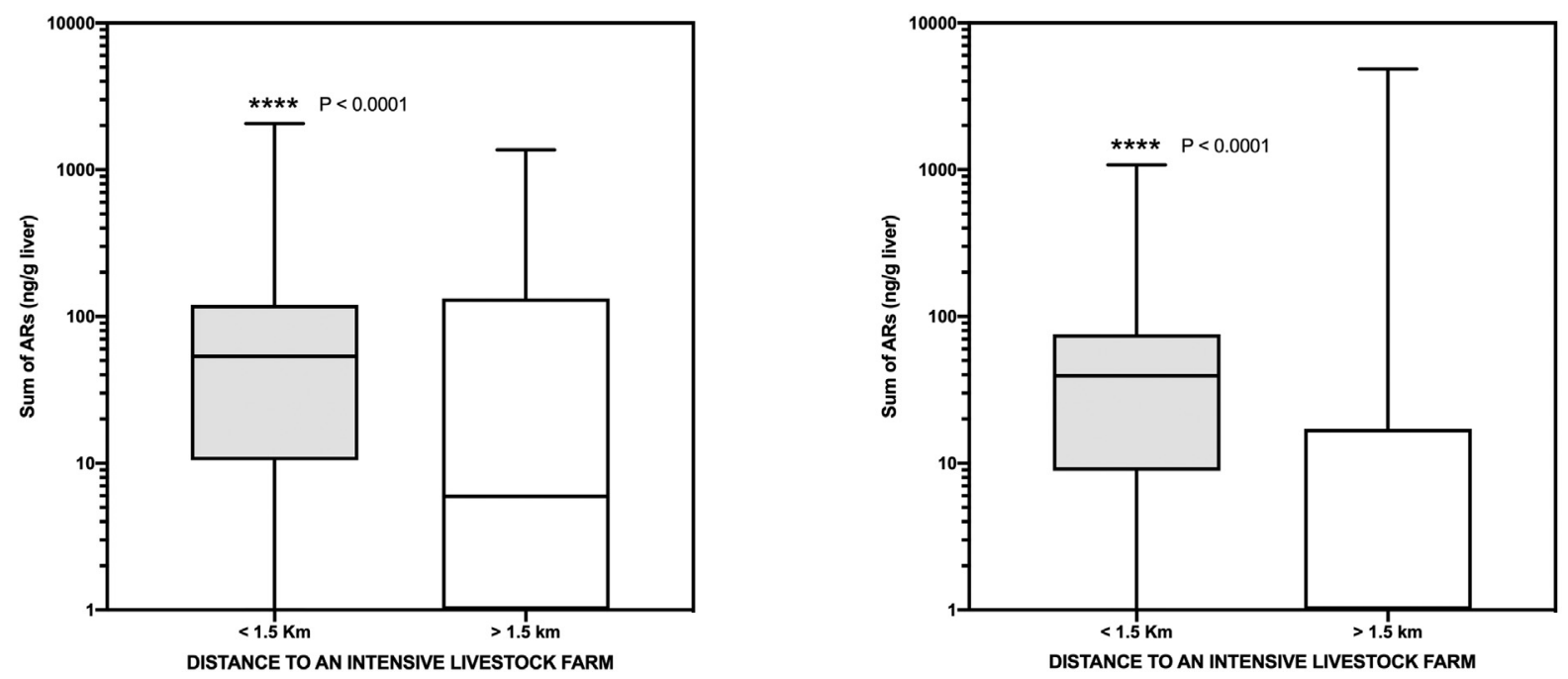

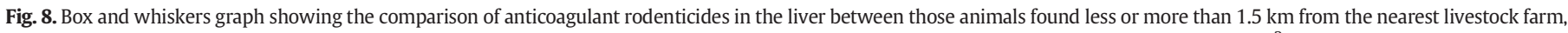

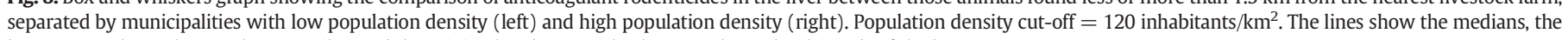
boxes cover the 25 th to 75 th percentiles, and the minimal and maximal values are shown by the ends of the bars. 
chemical control of rodent pests by alternative methods of physical and biological control where feasible.

Supplementary data to this article can be found online at https://doi. org/10.1016/j.scitotenv.2020.144386.

\section{CRediT authorship contribution statement}

Guarantor of integrity of the entire study: OPL

Study concepts and design: OPL

Literature research: $C R B, A A D, M A C P, A S P, A M M, O P L$

Laboratory work: CRB, AAD, ASP, NRS, ARH, AMM, MZ, LAHH, LDB, OPL

Data analysis: CRB, AAD, NRS, MACP, AMM, OPL

Statistical analysis: $\mathrm{LAHH}, \mathrm{OPL}$

Manuscript preparation: CRB, AAD, MACP, ASP, AMM, MZ, OPL

Manuscript editing: CRB, AAD, MACP, ASP, AMM, MZ, OPL

\section{Declaration of competing interest}

The authors declare that they have no known competing financial interests or personal relationships that could have appeared to influence the work reported in this paper.

\section{Acknowledgements}

This research was supported by the University of Las Palmas de Gran Canaria via a doctoral grant to the first author Cristian Rial-Berriel (ULPGC-012-2016) and also by the Spanish Ministry of Education, Culture and Sports via a doctoral grant to author Andrea Acosta-Dacal (FPU16-01888).

\section{References}

Alabau, E., Mentaberre, G., Camarero, P.R., Castillo-Contreras, R., Sanchez-Barbudo, I.S., Conejero, C., Fernandez-Bocharan, M.S., Lopez-Olvera, J.R., Mateo, R., 2020. Accumulation of diastereomers of anticoagulant rodenticides in wild boar from suburban areas: implications for human consumers. Sci. Total Environ. 738, 139828.

Albert, C.A., Wilson, L.K., Mineau, P., Trudeau, S., Elliott, J.E., 2010. Anticoagulant rodenticides in three owl species from Western Canada, 1988-2003. Arch. Environ. Contam. Toxicol. 58, 451-459.

Badry, A., Krone, O., Jaspers, V.L.B., Mateo, R., Garcia-Fernandez, A., Leivits, M., Shore, R.F., 2020. Towards harmonisation of chemical monitoring using avian apex predators: identification of key species for pan-European biomonitoring. Sci. Total Environ. $731,139198$.

Battin, J., 2004. When good animals love bad habitats: ecological traps and the conservation of animal populations. Conserv. Biol. 18, 1482-1491.

Berny, P., Vilagines, L., Cugnasse, J.M., Mastain, O., Chollet, J.Y., Joncour, G., Razin, M., 2015. VIGILANCE POISON: illegal poisoning and lead intoxication are the main factors affecting avian scavenger survival in the Pyrenees (France). Ecotoxicol. Environ. Saf. $118,71-82$.

Bishop, C.A., Williams, K.E., Kirk, D.A., Nantel, P., Reed, E., Elliott, J.E., 2016. A population model of the impact of a rodenticide containing strychnine on Great Basin Gophersnakes (Pituophis catenifer deserticola). Ecotoxicology 25, 1390-1405.

BOC. Orden 1489, de 28 de marzo de 2014, por el que se aprueba la estrategia para la erradicación del uso ilegal de veneno en el medio no urbano de Canarias. 2014. Boletin Oficial de Canarias (BOC) $n^{\circ}$ 70, de 9 de abril, 2014, pp. 9252-9324.

BOE. Ley 4/2010, del Catálogo Canario de Especies Protegidas. 2010. 4/2010, BOE nº 150 de 4 de junio, 2010, pp. 1-17.

Buck, A., Carrillo-Hidalgo, J., Camarero, P.R., Mateo, R., 2020. Organochlorine pesticides and polychlorinated biphenyls in common kestrel eggs from the Canary Islands: spatiotemporal variations and effects on eggshell and reproduction. Chemosphere 261, 127722.

Carrillo, J., Hernández, E.C., Nogales, M., Delgado, G., García, R., Ramos, T., 1994. Geographic variation in the spring diet of Falco tinnunculus L. on the islands of Fuerteventura and El Hierro (Canary islands). Bonner Zoologische Beitrage 45, 39-48.

Carrillo, J., González-Dávila, E., Ruiz, X., 2017. Breeding diet of Eurasian Kestrels Falco tinnunculus on the oceanic island of Tenerife. Ardea 105, 99-111.

Casagrande, S., Nieder, L., Di Minin, E., La Fata, I., Csermely, D., 2008. Habitat utilization and prey selection of the kestrel Falco tinnunculus in relation to small mammal abundance. Ital. J. Zool. 75, 401-409.

Christensen, T.K., Lassen, P., Elmeros, M., 2012. High exposure rates of anticoagulant rodenticides in predatory bird species in intensively managed landscapes in Denmark. Arch. Environ. Contam. Toxicol. 63, 437-444.

Dowding, C.V., Shore, R.F., Worgan, A., Baker, P.J., Harris, S., 2010. Accumulation of anticoagulant rodenticides in a non-target insectivore, the European hedgehog (Erinaceus europaeus). Environ. Pollut. 158, 161-166.
Eason, C.T., Murphy, E.C., Wright, G.R., Spurr, E.B., 2002. Assessment of risks of brodifacoum to non-target birds and mammals in New Zealand. Ecotoxicology 11, 35-48.

EC. Commission implementing regulation (EU) 2017/1382 renewing the approval of difethialone as an active substance for use in biocidal products of product-type 14 . Official Journal of the European Union 2017; L 194/45.

Elliott, J.E., Hindmarch, S., Albert, C.A., Emery, J., Mineau, P., Maisonneuve, F., 2014. Exposure pathways of anticoagulant rodenticides to nontarget wildlife. Environ. Monit. Assess. 186, 895-906.

Endepols, S., Klemann, N., Pelz, H.J., Ziebell, K.L., 2003. A scheme for the placement of rodenticide baits for rat eradication on confinement livestock farms. Prev Vet Med 58, 115-123.

Frankova, M., Stejskal, V., Aulicky, R., 2019. Efficacy of rodenticide baits with decreased concentrations of brodifacoum: validation of the impact of the new EU anticoagulant regulation. Sci. Rep. 9, 16779 .

Garcia-Heras, M.S., Cortes-Avizanda, A., Donazar, J.A., 2013. Who are we feeding? Asymmetric individual use of surplus food resources in an insular population of the endangered Egyptian vulture Neophron percnopterus. PLoS One 8, e80523.

Geduhn, A., Esther, A., Schenke, D., Gabriel, D., Jacob, J., 2016. Prey composition modulates exposure risk to anticoagulant rodenticides in a sentinel predator, the barn owl. Sci. Total Environ. 544, 150-157.

Godenau D, Corral Quintana S, López-Reillo P, Rivero Ceballos JL, Zapata Hernández V. Demographic and migration trends in the outermost regions: impacts on territorial, social and territorial cohesion? Executive summary - Canary Islands. 2012. European Union Regional Policy - Coordination of Outermost Regions Unit (EN), 2012.

Hindmarch, S., Elliott, J.E., McCann, S., Levesque, P., 2017. Habitat use by barn owls across a rural to urban gradient and an assessment of stressors including, habitat loss, rodenticide exposure and road mortality. Landsc. Urban Plan. 164, 132-143.

Hong, S.Y., Morrissey, C., Lin, H.S., Lin, K.S., Lin, W.L., Yao, C.T., Lin, T.E., Chan, F.T., Sun, Y.H., 2019. Frequent detection of anticoagulant rodenticides in raptors sampled in Taiwan reflects government rodent control policy. Sci. Total Environ. 691, 1051-1058.

Howald, G., Mineau, P., Elliott, J.E., Cheng, K.M., 1999. Brodifacoum poisoning of avian scavengers during rat control on a seabird colony. Ecotoxicology 8, 431-447.

Hughes, J., Sharp, E., Taylor, M.J., Melton, L., Hartley, G., 2013. Monitoring agricultural rodenticide use and secondary exposure of raptors in Scotland. Ecotoxicology 22, 974-984.

Johnston, J.J., Pitt, W.C., Sugihara, R.T., Eisemann, J.D., Primus, T.M., Holmes, M.J., Crocker, J., Hart, A., 2005. Probabilistic risk assessment for snails, slugs, and endangered honeycreepers in diphacinone rodenticide baited areas on Hawaii, USA. Environ. Toxicol. Chem. 24, 1557-1567.

Kenward, R.E., Arraut, E.M., Robertson, P.A., Walls, S.S., Casey, N.M., Aebischer, N.J., 2018. Resource-area-dependence analysis: inferring animal resource needs from homerange and mapping data. PLoS One 13, e0206354.

Lambert, O., Pouliquen, H., Larhantec, M., Thorin, C., L'Hostis, M., 2007. Exposure of raptors and waterbirds to anticoagulant rodenticides (difenacoum, bromadiolone, coumatetralyl, coumafen, brodifacoum): epidemiological survey in Loire Atlantique (France). Bull. Environ. Contam. Toxicol. 79, 91-94.

Lohr, M.T., Davis, R.A., 2018. Anticoagulant rodenticide use, non-target impacts and regulation: a case study from Australia. Sci. Total Environ. 634, 1372-1384.

Lopez-Perea, J.J., Camarero, P.R., Molina-Lopez, R.A., Parpal, L., Obon, E., Sola, J., Mateo, R., 2015. Interspecific and geographical differences in anticoagulant rodenticide residues of predatory wildlife from the Mediterranean region of Spain. Sci. Total Environ. 511, 259-267.

Lopez-Perea, J.J., Camarero, P.R., Sanchez-Barbudo, I.S., Mateo, R., 2019. Urbanization and cattle density are determinants in the exposure to anticoagulant rodenticides of nontarget wildlife. Environ. Pollut. 244, 801-808.

Lovett RA. Killing rats is killing birds. 2012. Nature news. Springer Nature, 2012.

Luzardo, O.P., Ruiz-Suarez, N., Valeron, P.F., Camacho, M., Zumbado, M., HenriquezHernandez, L.A., Boada, L.D., 2014. Methodology for the identification of 117 pesticides commonly involved in the poisoning of wildlife using GC-MS-MS and LC-MSMS. J. Anal. Toxicol. 38 (3), 155-163. https://doi.org/10.1093/jat/bku009.

Martínez, J.A., Zuberogoitia, I., 2004. Habitat preferences for Long-eared Owls Asio otus and Little Owls Athene noctua in semi-arid environments at three spatial scales. Bird Study 51, 163-169.

Mateo R, Carrillo J, Guitart R. p,p'-DDE residues in eggs of European kestrel Falco tinnunculus from Tenerife, Canary Islands, Spain. Bull. Environ. Contam. Toxicol. 2000; 65: 780-5.

Nakayama, S.M.M., Morita, A., Ikenaka, Y., Mizukawa, H., Ishizuka, M., 2019. A review: poisoning by anticoagulant rodenticides in non-target animals globally. J. Vet. Med. Sci. 81, 298-313.

Nogales, M., Nieves, C., 2007. Common raven (Corvus corax canariensis). In: Lorenzo, J.A. (Ed.). Atlas de aves nidificantes en el archipiélago canario (1997-2003). Dirección General de Conservación de la Naturaleza - Sociedad Española de Ornitología, Madrid, España, pp. 398-401.

Plaza, P.I., Martinez-Lopez, E., Lambertucci, S.A., 2019. The perfect threat: pesticides and vultures. Sci. Total Environ. 687, 1207-1218.

Quinn, J.H., Girard, Y.A., Gilardi, K., Hernandez, Y., Poppenga, R., Chomel, B.B., Foley, J.E., Johnson, C.K., 2012. Pathogen and rodenticide exposure in American badgers (Taxidea taxus) in California. J. Wildl. Dis. 48, 467-472.

Rattner, B.A., Lazarus, R.S., Elliott, J.E., Shore, R.F., van den Brink, N., 2014. Adverse outcome pathway and risks of anticoagulant rodenticides to predatory wildlife. Environ Sci Technol 48, 8433-8445.

Rial-Berriel, C., Acosta-Dacal, A., Zumbado, M., Luzardo, O.P., 2020. Micro QuEChERSbased method for the simultaneous biomonitoring in whole blood of 360 toxicologically relevant pollutants for wildlife. Sci. Total Environ. https://doi.org/10.1016/j. scitotenv.2020.139444. 
Rodríguez, B., Silverio, M., 2007. Halcón tagarote (Falco pelegrinoides). In: Lorenzo, J.A. (Ed.), Atlas de aves nidificantes en el archipiélago canario (1997-2003). Dirección General de Conservación de la Naturaleza - Sociedad Española de Ornitología, Madrid, España, pp. 183-187.

Ruiz-Suarez, N., Henriquez-Hernandez, L.A., Valeron, P.F., Boada, L.D., Zumbado, M., Camacho, M., Almeida-Gonzalez, M., Luzardo, O.P., 2014. Assessment of anticoagulant rodenticide exposure in six raptor species from the Canary Islands (Spain). Sci. Total Environ. 485-486, 371-376.

Ruiz-Suarez, N., Boada, L.D., Henriquez-Hernandez, L.A., Gonzalez-Moreo, F., SuarezPerez, A., Camacho, M., Zumbado, M., Almeida-Gonzalez, M., Del Mar, Travieso-Aja M., Luzardo, O.P., 2015. Continued implication of the banned pesticides carbofuran and aldicarb in the poisoning of domestic and wild animals of the Canary Islands (Spain). Sci. Total Environ. 505, 1093-1099.

Sanchez-Barbudo, I.S., Camarero, P.R., Mateo, R., 2012. Primary and secondary poisoning by anticoagulant rodenticides of non-target animals in Spain. Sci. Total Environ. 420, 280-288.

Seljetun, K.O., Eliassen, E., Madslien, K., Viljugrein, H., Vindenes, V., Oiestad, E.L., Moe, L., 2019. Prevalence of anticoagulant rodenticides in feces of wild red foxes (Vulpes Vulpes) in Norway. J. Wildl. Dis. 55, 834-843.

Serieys, L.E.K., Lea, A.J., Epeldegui, M., Armenta, T.C., Moriarty, J., VandeWoude, S., Carver, S., Foley, J., Wayne, R.K., Riley, S.P.D., Uittenbogaart, C.H., 2018. Urbanization and anticoagulant poisons promote immune dysfunction in bobcats. Proc. Biol. Sci. 285.
Simon, P., Dupuis, R., Costentin, J., 1994. Thigmotaxis as an index of anxiety in mice. Influence of dopaminergic transmissions. Behav. Brain Res. 61, 59-64.

Stone, W.B., Okoniewski, J.C., Stedelin, J.R., 2003. Anticoagulant rodenticides and raptors: recent findings from New York, 1998-2001. Bull. Environ. Contam. Toxicol. 70, 34-40.

SWGTOX, 2013. Scientific Working Group for Forensic Toxicology (SWGTOX) standard practices for method validation in forensic toxicology. J. Anal. Toxicol. 37, 452-474.

Thomas, P.J., Mineau, P., Shore, R.F., Champoux, L., Martin, P.A., Wilson, L.K., Fitzgerald, G., Elliott, J.E., 2011. Second generation anticoagulant rodenticides in predatory birds: probabilistic characterisation of toxic liver concentrations and implications for predatory bird populations in Canada. Environ. Int. 37, 914-920.

Thomsen SK, Kroeger CE, Bloom PH, Harvey ALV. Space use and home-range size of Barn Owls on Santa Barbara Island. Monographs of the Western North American Naturalist 2014; Article 21: 1-7.

Walker LA, Chaplow JS, Llewellyn NR, Pereira MG, Potter ED, Sainsbury AW, Shore RF. Anticoagulant rodenticides in predatory birds 2011: a Predatory Bird Monitoring Scheme (PBMS) report. 2013. Centre for Ecology \& Hydrology, Lancaster, UK, 2013, pp. 1-29.

Watt, B.E., Proudfoot, A.T., Bradberry, S.M., Vale, J.A., 2005. Anticoagulant rodenticides. Toxicol. Rev. 24, 259-269. 